\title{
Solid polymer fuel cell synthesis by low pressure plasmas: a short review
}

\author{
P. Brault ${ }^{1, a}$, S. Roualdès ${ }^{2}$, A. Caillard ${ }^{1}$, A.-L. Thomann ${ }^{1}$, J. Mathias ${ }^{1}$, J. Durand ${ }^{2}$, C. Coutanceau ${ }^{3}$, J.-M. Léger ${ }^{3}$, \\ C. Charles ${ }^{4}$, and R. Boswell ${ }^{4}$ \\ ${ }^{1}$ Groupe de Recherches sur l'Énergétique des Milieux Ionisés, UMR 6606, CNRS-Université d'Orléans, BP 6744, \\ 45067 Orléans Cedex 2, France \\ 2 Institut Européen des Membranes, UMR 5635, CNRS-Université de Montpellier II - CC 47, place Eugène Bataillon, \\ 34095 Montpellier Cedex 5, France \\ 3 Laboratoire de Catalyse en Chimie Organique, UMR 6503, CNRS-Université de Poitiers, 40 avenue du Recteur Pineau, \\ 86022 Poitiers Cedex, France \\ 4 Plasma Research Laboratory, Research School of Physical Science and Engineering Australian National University, \\ Canberra ACT 0200, Australia
}

Received: 21 September 2005 / Received in final form: 7 November 2005 / Accepted: 3 March 2006 Published online: 4 May 2006 - (C) EDP Sciences

\begin{abstract}
In this review, we report on the use of low pressure plasmas for elaborating materials at the heart of solid polymer fuel cells (SPFC), especially electrodes and the membrane electrolyte. Electrodes are formed using plasma sputtering techniques while the ion conducting membranes are built up using plasma polymerization. Fuel cell performance will be improved by these approaches. The electrode catalyst profile is optimized while membrane working temperature is increased and methanol crossover is lowered compared to conventional PEM fuel cells.
\end{abstract}

PACS. 81.15.Cd Deposition by sputtering - 81.15.Gh Chemical vapor deposition (including plasma-enhanced CVD, MOCVD, etc.) - 82.47.Nj Polymer-electrolyte fuel cells (PEFC)

\section{Introduction}

Fuel cells are often perceived as being part of the future solution to the 'energy crisis', providing 'clean' electricity with virtually no emissions. The development of fuel cells is considered to be an integral part of a sustainable 'hydrogen economy', in which hydrogen gas is produced using renewable sources of energy, and which offers the possibility of abundant energy with negligible emissions. Another advantage of fuel cells lies in the high efficiency for converting chemical energy into electricity and heat (hot water). Currently, one kind of fuel cell is expected to be attractive for many applications: the Proton Exchange Membrane Fuel Cell (PEMFC, or more generally, Solid Polymer Fuel Cell (SPFC) which includes Direct Methanol Fuel Cell -DMFC-, Direct Ethanol Fuel Cell -DEFC-) for which efficiency strongly depends on the electrode-membrane-assembly [1]. PEMFC systems provide an order of magnitude higher power density than any other fuel cell systems. The PEMFC can operate on reformed hydrocarbon fuels, with pre-treatment, and on air. The use of a solid polymer electrolyte eliminates the corrosion and safety concerns associated with liquid elec-

\footnotetext{
a e-mail: Pascal.Brault@univ-orleans.fr
}

trolyte fuel cells. Its low operating temperature of $80^{\circ} \mathrm{C}$ provides instant start-up and requires no thermal shielding to protect personnel. Recent advances in performance and design offer the possibility of lower cost than any other fuel cell system. The PEMFC has a high power density, and is very promising for mass market applications such as automotive and stationary small scale "combined heat and power" applications. New materials and new related synthesis processes are required to improve fuel cell efficiencies and costs. Among many methods, plasma deposition is a promising technique for elaborating these fuel cell materials. For this reason, we will focus on PEMFC for which low pressure plasma deposition is expected to improve membrane characteristics, especially higher operating temperatures using new polymer electrolyte thin films and electrodes by properly controlling catalyst content, morphologies and profiles.

\section{Plasma sputter deposition of catalysts onto electrodes}

A critical step is to lower catalyst content [2] and adjust consistently the catalyst profile in the so-called gas 


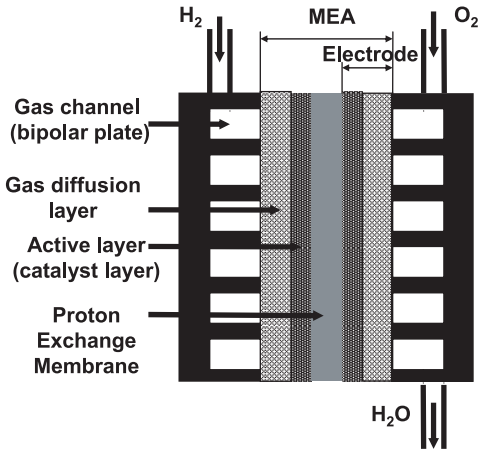

Fig. 1. Schematic of a proton exchange membrane fuel cell.

diffusion layer (GDL) in order to improve the fuel cell efficiency [3]. At the heart of the PEMFC (see Fig. 1) is the membrane electrode assembly (MEA).

The MEA is sandwiched by two flow field plates: the bipolar plates. The MEA consists of a dense proton exchange membrane, porous catalytic layers, and porous gas diffusion layers (GDL). Their thicknesses are typically 150 , 10 and $50 \mu \mathrm{m}$, respectively, but it depends on the fabrication method. These components are fabricated individually and then pressed together at high temperature $\left(140{ }^{\circ} \mathrm{C}\right)$ and pressure $\left(35 \mathrm{~kg} / \mathrm{cm}^{2}\right)$. The interface between the membrane and the electrodes is critical: it controls the internal resistance, electrochemical efficiency and thus the attainable power density [3].

Optimization of the electrode efficiency requires to correct distribution of the catalyst in the gas diffusion layer near the proton conductive membrane. A cross section view is drawn in Figure 2, which shows the three-fold contact: the catalyst is active when it is in close contact with both carbon particles (electron transport) and electrolyte (proton transport).

Many methods are commonly employed to form catalyst layers: chemical deposition such as colloidal, carbonyl, and chemical impregnation from salts. Physical deposition such as sputtering is less often used but is a promising technique due to the possible control of the catalyst content $[4-12,14,15]$. These references give many ways to reduce the catalyst content and eventually to increase the PEM fuel cell efficiency. Among them, Cha et al. $[8,11]$ and then Haut et al. [5] have deposited alternate sputtered platinum $(5 \mathrm{~nm})$ layers and painted layers of Nafion ${ }^{\circledR}$ and carbon ink directly on the membrane. They haved achieved PEMFC performance at about $40 \mu \mathrm{g}$ $\mathrm{Pt} / \mathrm{cm}^{2}$ nearly equivalent to higher loading $\left(0.5 \mathrm{mg} / \mathrm{cm}^{2}\right)$. Also, a porous graphite electrode is deposited in a plasmaenhanced chemical vapour deposition (PECVD) process, followed by a thin sputtered catalyst layer $[13,14]$. Hirano et al. [9] and Brault et al. [15] have sputtered platinum on uncatalyzed electrode resulting in $\mathrm{H}_{2} / \mathrm{O}_{2}$ cell performance at loading of $0.10 \mathrm{mg} \mathrm{Pt} / \mathrm{cm}^{2}$ equivalent to commercial fuel cells.

For illustrating how is handled plasma for fuel cell electrode design, we have used plasma sputtering with a TCP (Transformer Coupled Plasma) antenna. This process consists of a vacuum evaporation process that removes por- tions of a coating material (the platinum target in our case) and deposits a thin film of the target material into an adjacent porous gas diffusion layer. A low pressure Radio Frequency (RF) inductive plasma sputtering system has been constructed (APRIM VIDE) as displayed in Figure 3. An argon plasma is created in the stainless steel deposition chamber, with an $18 \mathrm{~cm}$ inner diameter and $25 \mathrm{~cm}$ long by using an external planar antenna (also known as TCP antenna) at $30 \mathrm{~W}$ input power and at an argon pressure of $5 \times 10^{-3}$ mbar. The excitation antenna is powered by a tunable frequency generator operating for the present experiments at $13.56 \mathrm{MHz}$. The electrodes are placed on a movable grounded substrate holder in front of the sputtering target with a target - substrate distance of $4.5 \mathrm{~cm}$. A base pressure of $\mathrm{P}_{0}=2 \times 10^{-8}$ mbar could be achieved using a primary/turbomolecular pump combination and during the experiment, an argon flow is fixed to 5 sccm using a mass flow meter. Such a setup, contrary to classical diode systems allows precise and independant control of both sputtering ion flux and biasing of target and substrate. This last parameter allows control of the energy of impinging ions on the substrate during deposition. This is expected to assist Pt diffusion into the porous carbon electrode [16]. Pt grows into the electrode up to $2 \mu \mathrm{m}$ depending on plasma parameters. The shape of the concentration profile is also dependent on plasma conditions, especially Argon pressure and substrate bias (see for example Fig. 4). Moreover, codeposition is possible by simply adding a biased target. This is very useful for fuel cells, because poisoning of the catalyst is lowered by Pt codeposition with another element. For the Direct Methanol Fuel Cell, the anode catalyst is chosen to be a codeposition of $\mathrm{Pt}$ and $\mathrm{Ru}$, eventually leading to a $\mathrm{Pt}_{x} \mathrm{Ru}_{y}$ alloy. Plasma sputtering codeposition, by independent biasing of targets, is able to provide various concentration profiles of the two elements. Figure 5 displays the $\mathrm{Pt}$ and $\mathrm{Ru}$ concentration profiles. The concentrations are $70 \% \mathrm{Pt}$ atoms and $30 \% \mathrm{Ru}$ atoms respectively. The $\mathrm{Pt}$ and $\mathrm{Ru}$ atoms have been simultaneously sputtered. It is expected that a bimetallic catalyst is formed and the composition is independent of the depth. When operating with hydrogen, fuel cells, built with such electrodes, deliver power density in the range 0.4 to $0.7 \mathrm{~W} / \mathrm{cm}^{2}$ and $60 \mathrm{~mW} / \mathrm{cm}^{2}$. These values are similar to power densities delivered with commercial electrodes. But in our cases, the catalyst content is 5 to 10 times less. So the mass power density is increased by the same factors. This proves that designing a well suited catalyst concentration profile in the electrode allows us to reduce the catalyst content while keeping good performances. As a conclusion, it is clear that plasma sputtering offers a good opportunity to design fuel cell electrodes with various compositions, concentrations profile depths and shapes.

\section{Plasma polymerization of proton conducting membranes}

Ion conductive membranes, in particular Nafion ${ }^{\circledR}$ developed by DuPont, find widespread applications in 


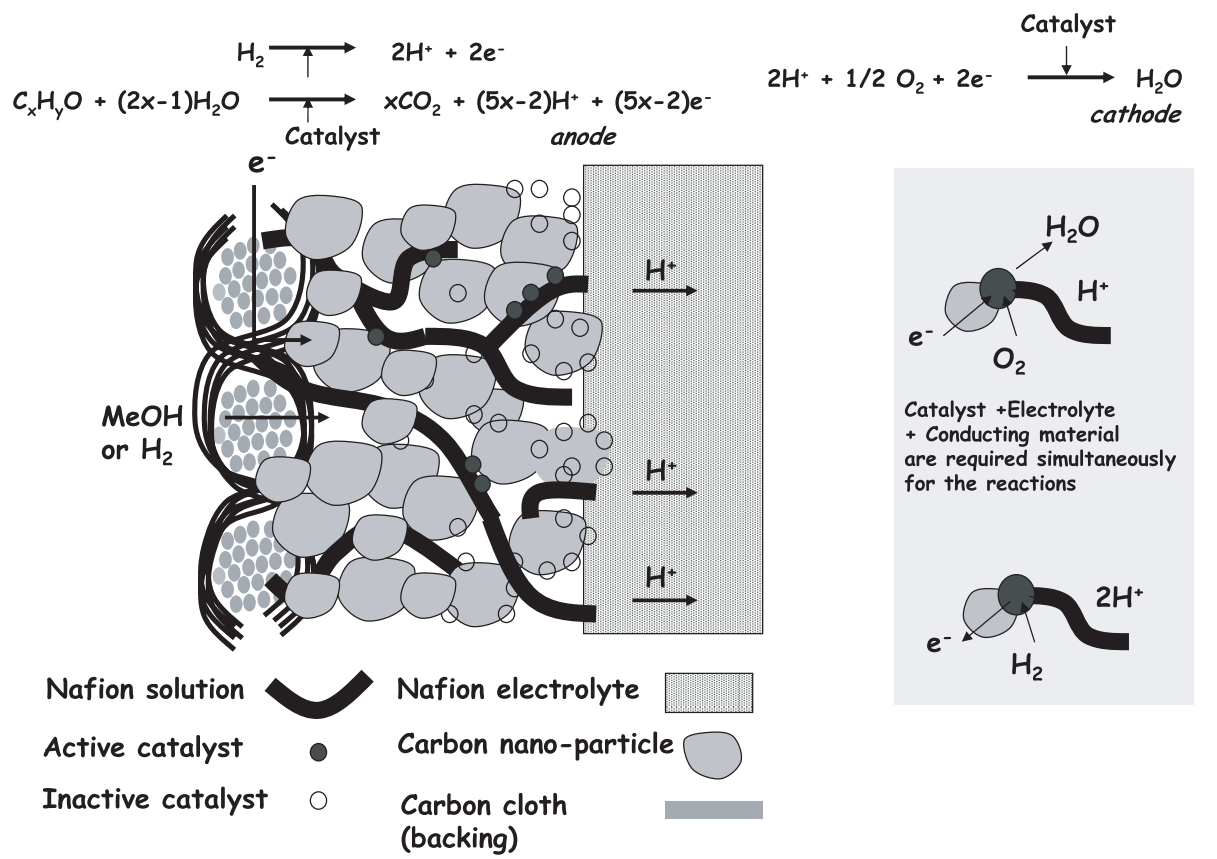

Fig. 2. Schematic of the electrochemical processes in a proton exchange membrane fuel cell powered with either methanol or hydrogen. The insert shows the necessity of having an ion conducting polymer, catalyst and conducting support (here carbon) forming a three-fold contact.

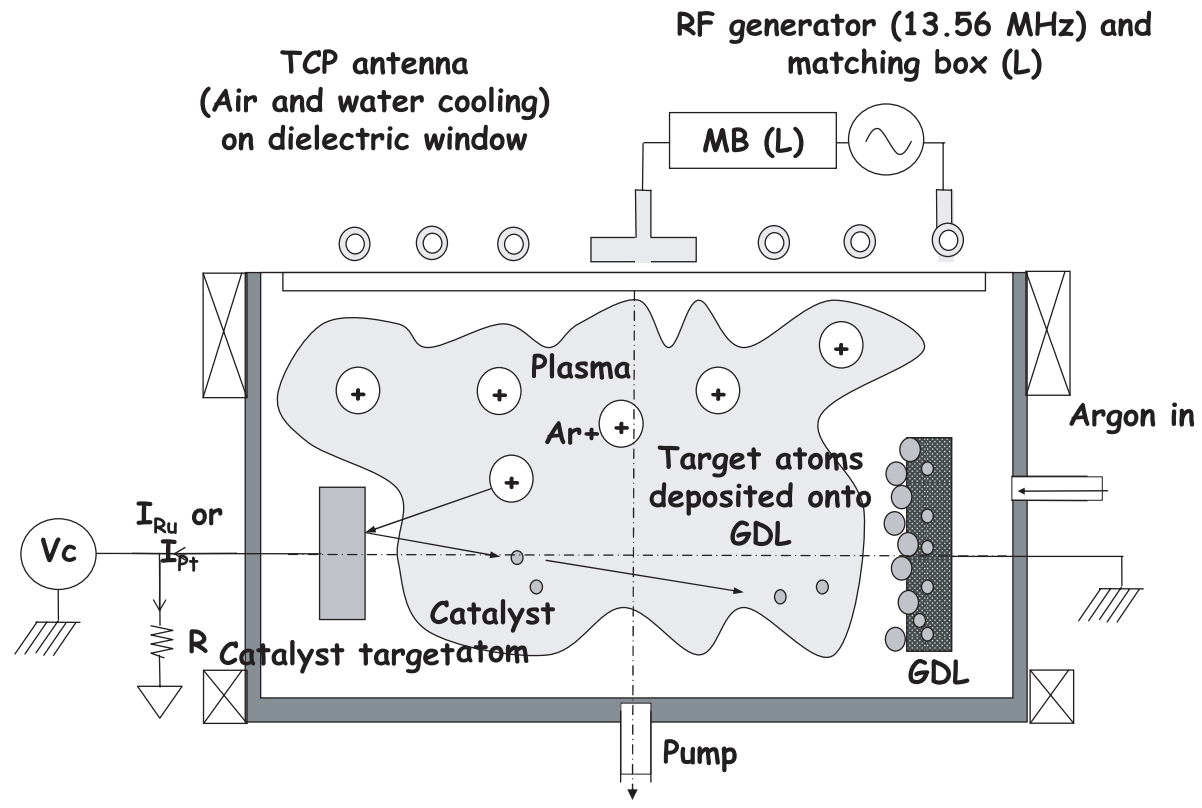

Fig. 3. Schematic of the high density low pressure plasma sputtering reactor.

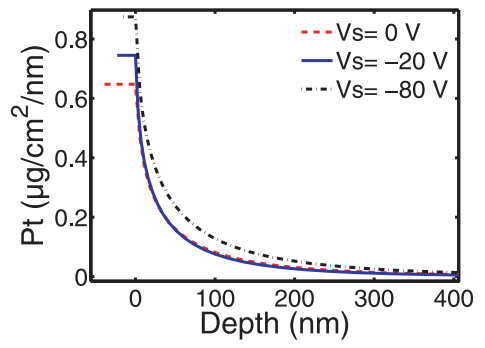

Fig. 4. Platinum concentration profiles into the electrode. electrolyzers, batteries or fuel cells $[1,2]$. Nafion ${ }^{\circledR}$ has a fluorocarbon backbone with side chains that carry terminal sulfonic acid groups (see Fig. 6). It combines the outstanding chemical and thermal stability of Teflon with the highly acidic character of sulfuric acid, and thus, exhibits hydrophilic and hydrophobic properties at the same time. In general, thin membranes are appreciated because of the lower resistance, making the process more efficient. In $\mathrm{H}_{2} / \mathrm{O}_{2}$ fuel cells thinner membranes also provide an improved water management due to the enhanced back 


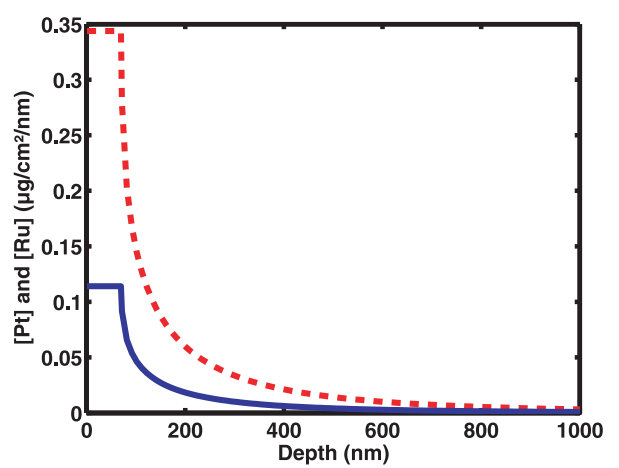

Fig. 5. Example of $\mathrm{Pt}$ and $\mathrm{Ru}$ concentration profiles into the electrode. Composition is $70 \% \mathrm{Pt}$ atoms and $30 \% \mathrm{Ru}$ atoms and simultaneously co-sputtered.

diffusion of production water from the cathode to the anode side.

Plasma polymerization is a powerful and widely used method to deposit thin and uniform polymer films on various substrates. The highly cross-linked structure of these plasma membranes provides higher thermal and chemical stability than the conventional polymerized membranes, which increases their application in a wide range of fields and also their lifetime. Plasma polymers can also be used as effective diffusion barriers [17]. This is interesting for the direct methanol fuel cell (DMFC), which suffers not only from the sluggish anode oxidation reaction, but also from methanol crossover towards the cathode side. Nafion ${ }^{\circledR}$ is permeable for both water and methanol, resulting in an insufficient separation of the two reactants and thus, a decreased cathode potential [18]. Membranes with high proton conductivity, but low methanol permeability are required for DMFC applications. The thin thickness of plasma-polymerized membranes is a serious advantage to ensure a good contact with the electrodes of PEMFC. Several research groups have explored the possibility of using plasma polymerization to prepare polymer electrolyte membranes by copolymerization of trifluoromethane sulfonic acid $\left(\mathrm{CF}_{3} \mathrm{SO}_{3} \mathrm{H}\right)$, chlorosulfonic acid, $\mathrm{SO}_{2}, \mathrm{CO}_{2}$, phosphonic acid with different fluorocarbons. Generally, these plasma films are deposited in a glow discharge between two capacitively coupled inner disk electrodes. Most of these studies have shown that sulfur moieties incorporated into plasma polymers are a mixture of sulfonic acid and sulfone groups. Inagaki and his co-workers have prepared plasma polymer electrolytes using $\mathrm{SO}_{2}$ with pentafluorobenzene, tetrafluorobenzene and perfluorobenzene respectively [19-21]. In this study, the highest ionic conductivity of $4.3 \times 10^{-2} \mathrm{mS}^{-\mathrm{cm}^{-1}}$ was measured for the plasma polymer formed from tetrafluorobenzene/ $\mathrm{SO}_{2}$ mixture. Several works of Ogumi and his co-workers have followed; the membranes prepared using $\mathrm{CF}_{3} \mathrm{SO}_{3} \mathrm{H}$ and $\mathrm{CF}_{3} \mathrm{CH}_{2} \mathrm{Cl}$ have shown conductivities in the range 0.025-0.05 mS.cm ${ }^{-1}[22,23]$. Uchimoto et al. have described the plasma polymerization of 1,3-butadiene and methylbenzene sulfonate and measured a conductivity of $0.18 \mathrm{mS} . \mathrm{cm}^{-1}[24,25]$. Yasuda et al. have measured the same conductivity for a membrane synthesized by copoly-

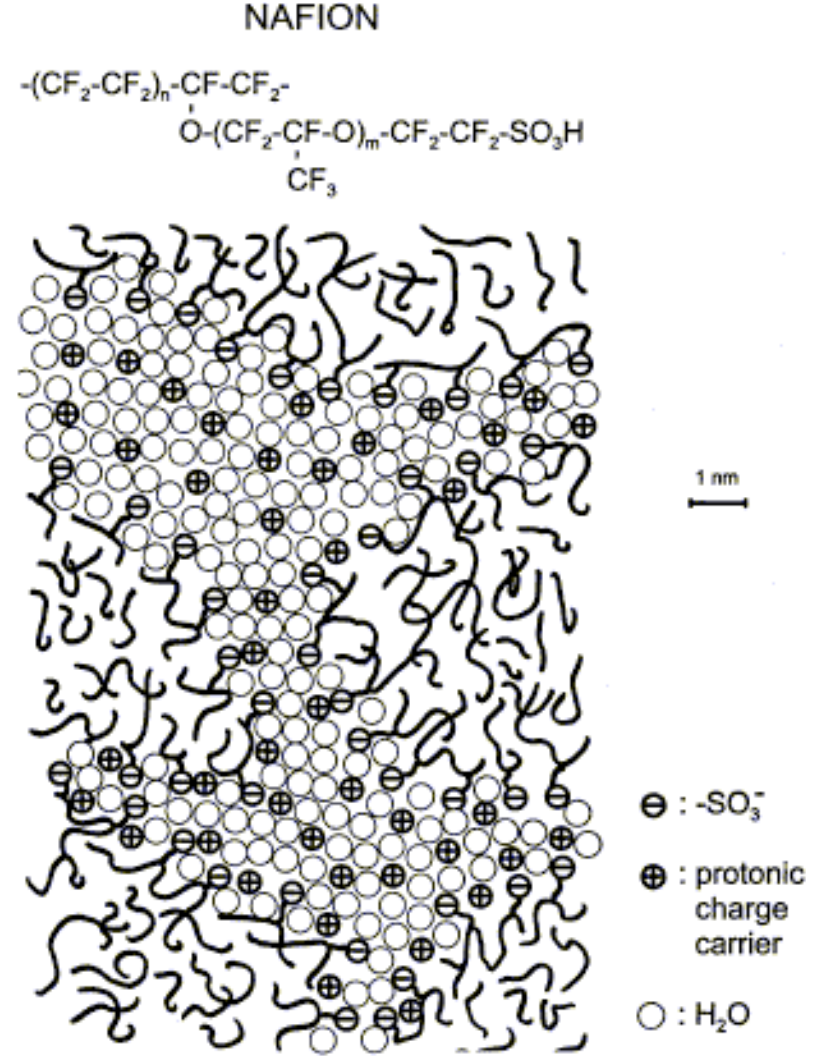

Fig. 6. Formula and model of proton transport in Nafion ${ }^{\circledR}$.

merization of hexafluoropropylene and $\mathrm{CF}_{3} \mathrm{SO}_{3} \mathrm{H}[26,27]$. Plasma polymerization of trifluoroethylene and $\mathrm{CF}_{3} \mathrm{SO}_{3} \mathrm{H}$ mixture investigated by Brumlik has led to a conductivity of $0.58 \mathrm{mS} . \mathrm{cm}^{-1}$ [28]. Other studies show lower conductivities [29]. In all of these studies it is observed that the ionic conductivities of the plasma-polymerized films were substantially lower than that of Nafion ${ }^{\circledR}$. More recently, Mex and his co-workers have deposited tetrafluoroethylene/vinylphosphonic acid and tetra-fluoroethylene- $\mathrm{H}_{2} \mathrm{O}$ plasma polymers; these films have shown surprisingly good conductivities, higher than that of Nafion ${ }^{\circledR}$, as well at $30{ }^{\circ} \mathrm{C}$ as well as at higher temperatures $[13,14]$. Finsterswalder et al. have reported carbon fluorine based membranes containing sulfonic acid groups prepared by an ion beam assisted plasma polymerization process starting from a solid PTFE target rather than using glow discharge [30]. Another important feature of new membrane is their ability to operate at higher temperatures than Nafion ${ }^{\circledR}$, namely greater than $90^{\circ} \mathrm{C}$. As an example, we describe proton exchange membranes with sulfonic acid groups and fluoro-carbons prepared by plasma polymerization [31]. Trifluoromethane sulfonic acid $\left(\mathrm{CF}_{3} \mathrm{SO}_{3} \mathrm{H}\right)$ was chosen to be plasma polymerized with a linear $(1,3-$ butadiene) or an aromatic (styrene) monomer, respectively. Two types of plasma reactors were used to prepare the polymer films. In the first type the film deposition region is situated in the glow discharge, and in the second one the glow discharge and the film deposition region are separated (post-discharge configuration). 
Table 1. Atomic percentage of sulfonic acid groups and protonic conduction properties of plasma polymers.

\begin{tabular}{|c|c|c|c|c|c|}
\hline Kind of discharge & $\begin{array}{c}\text { Nature of the } \\
\text { carbonated } \\
\text { monomer }\end{array}$ & Sample name & $\%-\mathrm{SO}_{3} \mathrm{H}$ & $\begin{array}{c}\text { Conductivity } \sigma \\
\left(\mathrm{mS}^{\left.-\mathrm{cm}^{-1}\right)}\right.\end{array}$ & $\begin{array}{c}\text { Specific } \\
R S(\text { resistance }) \\
\text { for } e=1 \mu \mathrm{m}\left(\Omega . \mathrm{cm}^{2}\right)\end{array}$ \\
\hline \multirow{7}{*}{ Glow discharge } & \multirow{6}{*}{1,3 butadiene } & GBu50/0.3 & 1.1 & $8.0 \times 10^{-4}$ & 125 \\
\hline & & GBu50/1 & 1.2 & $1.1 \times 10^{-3}$ & 91 \\
\hline & & GBu30/0.3 & 1.5 & $2.2 \times 10^{-3}$ & 45 \\
\hline & & GBu30/1 & 2.9 & $4.0 \times 10^{-4}$ & 250 \\
\hline & & GBu10/0.3 & 1.8 & $4.0 \times 10^{-5}$ & 2500 \\
\hline & & GBu10/1 & 1.8 & - & - \\
\hline & styrene & GSt30/1 & 2.8 & $2.5 \times 10^{-3}$ & 40 \\
\hline \multirow[t]{2}{*}{ After glow discharge } & styrene & AGSt50/1 & - & $7.0 \times 10^{-2}$ & 1.4 \\
\hline & styrene & AGSt50/3.5 & 5.0 & $9.8 \times 10^{-2}$ & 1.0 \\
\hline
\end{tabular}
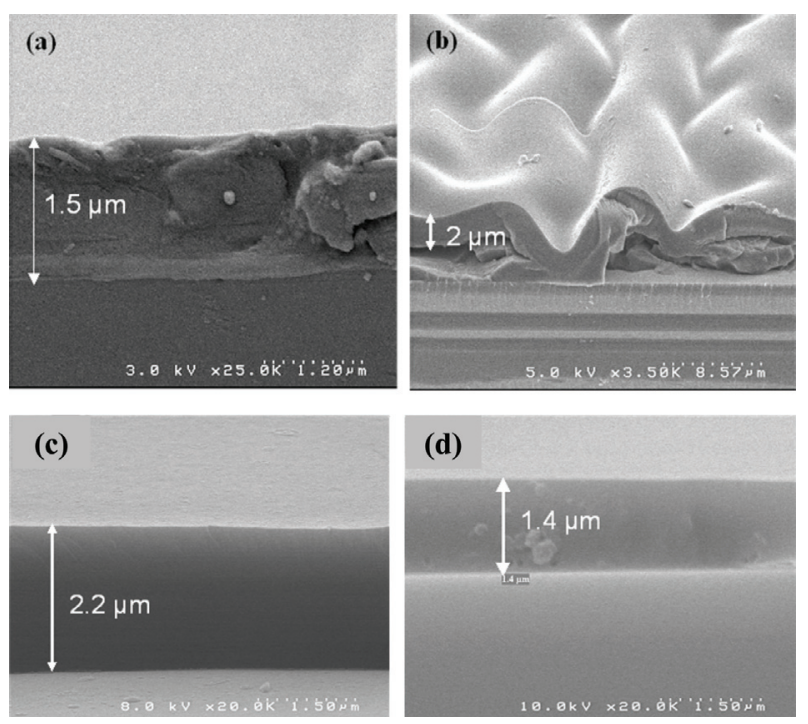

Fig. 7. Scanning electron micrographs of the cross-section of plasma-polymerized thin films obtained in the glow discharge. (a) GBu10/1. (b) GSt30/1, in the after glow discharge. (c) AGSt50/1. (d) AGSt50/3.5. The a/b numbers following the deposit name are $\mathrm{a}=$ input power $(\mathrm{W})$ and $\mathrm{b}=$ ratio of the partial pressure of $\mathrm{CF}_{3} \mathrm{SO}_{3} \mathrm{H}$ to carbonated monomer.

SEM pictures of the plasma polymers obtained in the glow discharge are shown in Figures 7a and b. The plasmapolymerized membranes prepared with the $\mathrm{CF}_{3} \mathrm{SO}_{3} \mathrm{H} / 1,3-$ butadiene mixture ( $\mathrm{GBu}$ films) are dense, flat, uniform and free from defects; their deposition rate is measured in the range $5-8 \mu \mathrm{m} \cdot \mathrm{h}^{-1}$. The plasma polymers synthesized in the after glow discharge from the $\mathrm{CF}_{3} \mathrm{SO}_{3} \mathrm{H}$-styrene mixture (AGSt films) are shown in Figures 7c, d. These films are flat, uniform and free from defects; their deposition rate is between 3 and $5 \mu \mathrm{m} \cdot \mathrm{h}^{-1}$.

From a chemical point of view, sulfur moieties can be incorporated into plasma polymers as sulfonic acid groups and/or sulfone groups. Sulfonic acid groups are predominant in plasma polymers formed in the after glow discharge whereas it is sulfone groups in plasma polymers formed in the glow discharge, due to a too high fragmentation of the $\mathrm{CF}_{3} \mathrm{SO}_{3} \mathrm{H}$ monomer in this latter configuration. Several studies $[24,26]$ have effectively shown that in drastic plasma conditions, plasma polymers are likely to contain very little and even no sulfonic acid groups as the sulfonic acid groups are completely decomposed in the plasma. Infrared Fourier Transform and X-ray Photoelectron Spectroscopies measurements suggest that plasma films synthesized in the after glow discharge are expected to be better materials for proton conductive membranes than films formed in the glow discharge.

Proton conductivity is also a very important parameter for the electrolyte. Table 1 lists the proton conductivity values and the specific resistances RS (product of the resistance by the membrane area) for plasma membranes with thickness equal to $1 \mu \mathrm{m}$; the first characteristic is related to the intrinsic conduction properties of materials while the second one gives information on the real efficiency of plasma films as proton conducting membranes. Plasma polymers formed in the glow discharge show the lowest proton conductivities between $4.0 \times 10^{-5}$ and $2.5 \times 10^{-3} \mathrm{mS}^{-\mathrm{cm}^{-1}}$; the maximum value is obtained for the GSt30/1 film synthesized from styrene. Plasma polymers prepared in the after glow discharge from the $\mathrm{CF}_{3} \mathrm{SO}_{3} \mathrm{H}$-styrene mixture have much higher conductivities up to $9.8 \times 10^{-2} \mathrm{mS} \mathrm{cm}^{-1}$. Taking into account the conclusions drawn from structural analysis of materials, we can conclude that the proton conduction capacity of a plasma material is all the more increased when its density is low (high water and proton mobility) and its sulfonic acid content is high (enhancement of proton exchange). A proton conductivity of $9.6 \mathrm{mS} . \mathrm{cm}^{-1}$ was measured for the Nafion ${ }^{\circledR} \mathrm{N}-117$ membrane in the same experimental conditions. This value inherent in the hydration state of the membrane is at the lower limit of the typical range reported for proton conductivities of $\mathrm{Nafion}^{\circledR}$ N-115 or N-117: 10-100 mS.cm ${ }^{-1}$ [32-34]. Even best conductive plasma-polymerized films show proton conductivities much lower than the Nafion ${ }^{\circledR} \mathrm{N}-117$ membrane. Now, we have previously shown that the sulfonic acid content in plasma materials is higher than that in Nafion ${ }^{\circledR}$; this means that the low proton conduction capacity of plasma materials can be ascribed to their low swelling, directly related to their high cross-linking inherent in their synthesis process. Nevertheless, the gap in conductivity between plasma membranes and Nafion ${ }^{\circledR}$ is compensated by the difference in thickness between both kinds of membranes. 
As is shown in Table 1, plasma films with thickness equal to $1 \mu \mathrm{m}$ synthesized from the $\mathrm{CF}_{3} \mathrm{SO}_{3} \mathrm{H}$-styrene mixture in the after glow discharge configuration show specific resistances (1.0-1.4 $\left.\Omega . \mathrm{cm}^{2}\right)$ lower than the Nafion ${ }^{\circledR} \mathrm{N}-117$ membrane $\left(1.9 \Omega . \mathrm{cm}^{2}\right)$.

\section{Conclusion}

In conclusion, low pressure plasmas are challenging techniques for producing SPFC materials. Notably, plasma sputtering is interesting for electrode synthesis with low catalyst contents. The unique feature of this technique is to optimize catalyst concentration profiles in the electrodes. Gas phase plasma polymerization using Plasma Enhanced Chemical Vapor Deposition, is shown to be able to produce low thickness polymer electrolyte membranes. Moreover, these membranes have lower methanol crossover, higher operating temperatures (up to $120^{\circ} \mathrm{C}$ ) and similar ion conductivities to commercial Nafion ${ }^{\circledR}$ membranes.

We gratefully thank GdR 2479 PACEM, Université d'Orléans, SPI-CNRS, ACI ECD 2004 (Ministry of Research) for grants and constant support.

\section{References}

1. Fuel Cell Handbook 6th Edition (DOE/NETL-2002/1179, US Dept Of Energy, 2002)

2. H.A. Gasteiger, J.E Panels, S.G. Yan, J. Power Sources 127, 162 (2004)

3. S. Litster, G. McLean, J. Power Sources 130, 61 (2004) and references therein

4. T.H. Yang, Y.G. Yoon, C.S. Kim, S.H. Kwak, K.H. Yoon, J. Power Sources 106, 328 (2002)

5. A.T. Haug, R.E. White, J.W. Weidner, W. Huang, S. Shi, T. Stoner, N. Rana, J. Electrochem. Soc. 149, A280 (2002)

6. A.T. Haug, R.E. White, J.W. Weidner, W. Huang, J. Electrochem. Soc. 149, A862 (2002)

7. A.T. Haug, R.E. White, J.W. Weidner, W. Huang, S. Shi, N. Rana, S. Grunow, T. Stoner, J. Electrochem. Soc. 149, A868 (2002)

8. S.Y. Cha, W.M. Lee, J. Electrochem. Soc. 146, 4055 (1999)

9. S. Hirano, J. Kim, S. Srinivasan, Electrochim. Acta 42, $1587(1997)$

10. S. Mukerjee, S. Srinivasan, A.J. Appleby, Electrochim. Acta 38, 1661 (1993)

11. R. O'Hayre, S.J. Lee, S.W. Cha, F.B. Prinz, J. Power Sources 109, 483 (2002)
12. Y.-G. Chun, C.-S. Kim, D.-H. Peck, D.-R. Shin, J. Power Sources 71, 174 (1998)

13. L. Mex, J. Müller, Membrane Technology 115, 5 (1999)

14. L. Mex, N. Ponath, J. Müller, Fuel Cell Bulletin 39, 9 (2001)

15. P. Brault, A. Caillard, A.L. Thomann, J. Mathias, C. Charles, R.W. Boswell, S. Escribano, J. Durand, T. Sauvage, J. Phys. D 37, 3419 (2004)

16. A. Caillard, P. Brault, J. Mathias, C. Charles, R.W. Boswell, T. Sauvage, Surf. Coat. Tech. 200, 391 (2005)

17. H. Yasuda, J. Membrane Sci. 18, 273 (1984)

18. X. Ren, T.A. Zawodzinski, F. Uribe, H. Dai, S. Gottesfeld, Proton Conducting Membrane Fuel Cells I, edited by S. Gottesfeld, G. Halpert, A. Landgrebe (The Electrochemical Society, Pennington, NJ, 1995), p. 284

19. N. Inagaki, S. Tasaka, Y. Horikawa, J. Polym. Sci. Pol. Chem. 27, 3495 (1989)

20. N. Inagaki, S. Tasaka, T. Kurita, Polym. Bull. 22, 15 (1989)

21. N. Inagaki, S. Tasaka, Z. Chengfei, Polym. Bull. 26, 187 (1991)

22. Z. Ogumi, Y. Uchimoto, K. Yasuda, Z.-I. Takehara, Chem. Lett. 953 (1990)

23. Z. Ogumi, Y. Uchimoto, Z.-I. Takehara, J. Electrochem. Soc. 137, 3319 (1990)

24. Y. Uchimoto, K. Yasuda, Z. Ogumi, Z.-I. Takehara, A. Tasaka, T. Imahigashi, Ber. Bunsenges. Phys. Chem. 97, 625 (1993)

25. Y. Uchimoto, E. Endo, K. Yasuda, Y. Yamasaki, Z.-I. Takehara, Z. Ogumi, O. Kitao, J. Electrochem. Soc. 147, $111(2000)$

26. K. Yasuda, Y. Uchimoto, Z. Ogumi, Z.-I. Takehara, J. Electrochem. Soc. 141, 2350 (1994)

27. K. Yasuda, Y. Uchimoto, Z. Ogumi, Z.-I. Takehara, Ber. Bunsenges. Phys. Chem. 98, 631 (1994)

28. C.J. Brumlik, A. Parthasarathy, W.-J. Chen, C.R. Martin, J. Electrochem. Soc. 141, 2273 (1994)

29. K. Yoshimura, T. Minaguchi, H. Nakano, T. Tatsuta, O. Tsuji, K. Toyozawa, T. Abe, Z. Ogumi, J. Photopolym. Sci. Techn. 13, 13 (2000)

30. F. Finsterwalder, G. Hambitzer, J. Membr. Sci. 185, 105 (2001)

31. H. Mahdjoub, S. Roualdès, P. Sistat, N. Pradeilles, J. Durand, G. Pourcelly, Fuel Cells 5, 277 (2005)

32. T.A. Zawodzinski Jr., C. Derouin, S. Rodzinski, R.J. Sherman, V.T. Smith, T.E. Springer, S. Gottesfeld, J. Electrochem. Soc. 140, 1041 (1993)

33. T.A. Zawodzinski Jr., T.E. Springer, F. Uribe, S. Gottesfeld, Solid State Ionics 60, 199 (1993)

34. Y. Sone, P. Ekdunge, D. Simonsson, J. Electrochem. Soc. 143, $1254(1996)$ 